\title{
CUTTING TECHNIQUES FOR PASTURE YIELDS ON HILL COUNTRY
}

\author{
J. E. Radcliffe \\ Department of A griculture, Lincoln
}

\section{Summary}

Production of pastures measured by the trim and difference cutting techniques are presented for sites on North Island hill pastures and South Island improved tussock grasslands. On North Island sites the trim technique consistently gave higher yields. On South Island sites, interim results have shown no consistent overall effect, although large differences in yields have been measured at some cuts.

The number of samples required by the trim :echnique to give a standard error $\pm 10 \%$ of mean yield was 30 on North Island sites (sample size $0.3 \mathrm{~m} \times 0.2 \mathrm{~m}$ ) and 15 on South Island sites (sample size $0.5 \mathrm{~m} \times 0.5 \mathrm{~m}$ ). The difference technique was much more variable and required 5 and 20 times more samples on North and South Island sites, respectively, to give a standard error $\pm 10 \%$ of the mean yield.

On another North Island site, large, laxly trimmed sampling sites gave higher yields than smaller, severely trimmed sampling sites and one large sample $(3.4 \mathrm{~m} \mathrm{x} 1.0 \mathrm{~m})$ generally gave similar precision in yields to 6 or 7 smaller samples $(0.8 \mathrm{~m} \mathbf{x} 0.3 \mathrm{~m})$.

\section{INTRODUCTION}

Ali measurements of pasture yields which involve cutting and weighing are greatly influenced by the method of cutting, the height and frequency of cutting, and the. grazing management employed. These factors interact with plant growth to influence dry matter yields. In this paper, two methods of cutting are discussed. These are the trim technique which measures regrowth from a previously trimmed site, and the difference technique which uses measurements of pasture available at the beginning and end of a period to estimate growth within that period.

Previous comparisons of the trim and difference techniques used here have given variable results. On Agrostis pasture in England, both techniques gave similar yields of starch equivalent in one year, but the trim technique gave higher yields in the second year (Boyd, 1949). However, on Agrostis pasture in Wales, the difference technique gave higher dry matter yields 
TABLE 1: EXPERIMENTAL DET.AILS

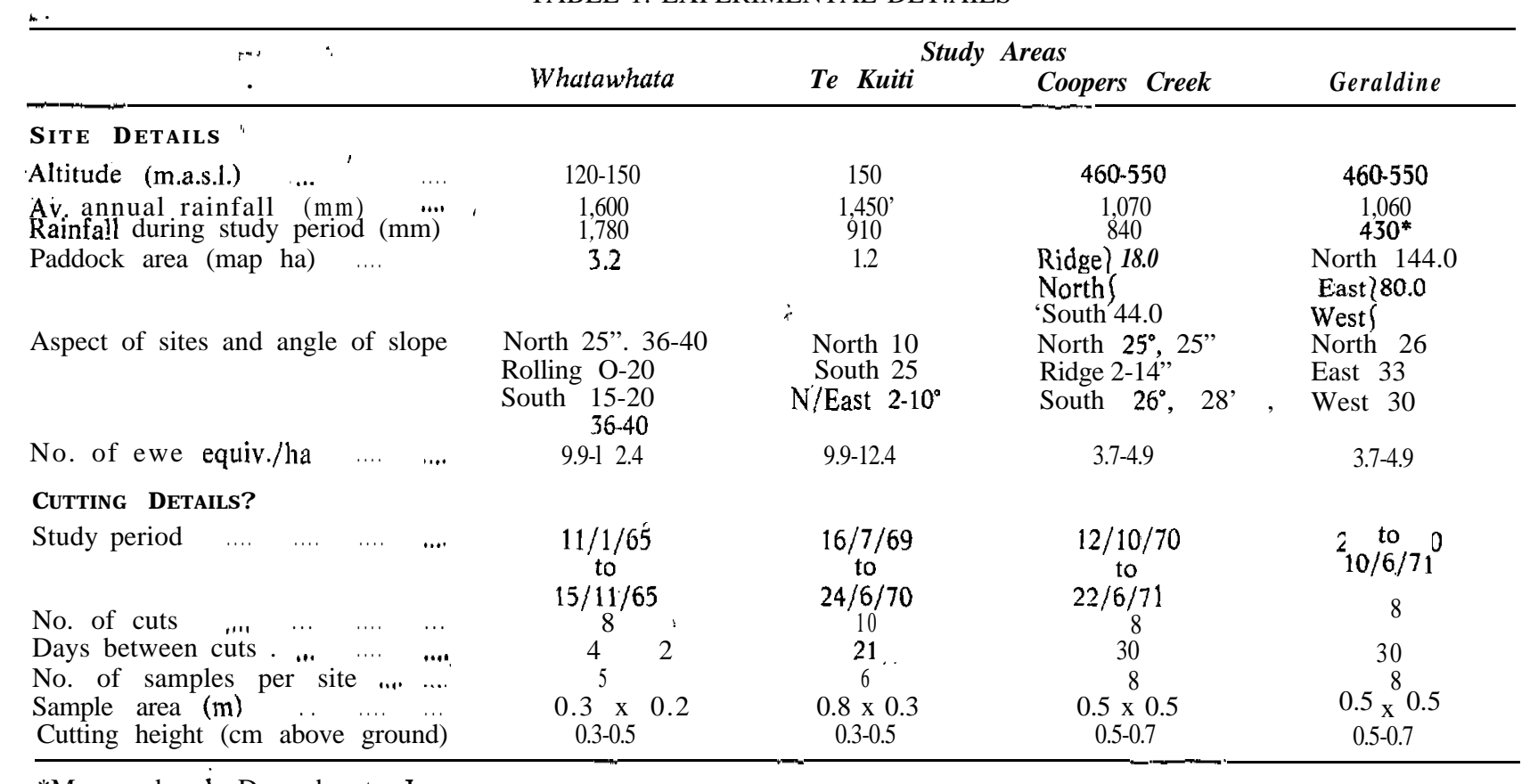

*Measured only December to June

$\nmid$ Does not include comparisons of sample size and cutting heighr at Te Kuiti (see text). 
(Davies et al., 1950). On Poa pratensis pasture in U.S.A. the trim technique gave higher dry matter yields (Nevens, 1945) and on browntop-dominant hill pasture in New Zealand, the trim technique gave higher dry matter yields (Radcliffe et al., 1968). However, on ryegrass pasture in New Zealand, the difference technique gave higher dry matter yields one year and lower yields the second year (Lynch and Mountier, 1954). Variations in experimental techniques, such as height and frequency of cutting, pasture components and grazing management, have probably contributed to these anomalous results.

Cutting techniques which approximate normal grazing management are clearly desirable, but difficult to attain in practice, particularly on New Zealand hill country, where grazing management is often a combination of set-stocking, rotational grazing, and occasional seasonal spelling. Large paddocks, varied topography, a range of pasture species and growth rates, and irregular grazing pressure contribute 'to the range of pasture heights commonly encountered on hill pasture. Previous yield measurements on hill pastures in North Island, New Zealand, have been made by Suckling $(1954,1964)$ who clipped un. trimmed herbage from three large cages per paddock, and br Radcliffe et al. (1968) who cut 30 smaller samples on a $\mathrm{ri}$ stricted random basis per paddock.

In this paper yield data are presented from:

(1) Topdressed Waikato hill pasture and improved sheep tussock grasslands in Canterbury using both the trim 'and difference cutting techniques.

(2) Topdressed King Country pasture 'using two sample sizes and cutting heights with a trim technique.,

Although the data are necessarily selective and limited (three experiments are still in progress) they cleàrly illustrate the effect of cutting technique on yield.

\section{EXPERIMENTAL}

A locality map is given in Fig: 1 . Some details of study areas and sampling are given. in Table 1.

ist?

Both the difference and trim cutting techniques were used at Whatawhata (on.:Waingaro: steepland. soil (Soil Bureau; 1954) ), Coopers Creek and Geraldine (on Hurunui steepland soil. (Soil Bureau, 1968)): 


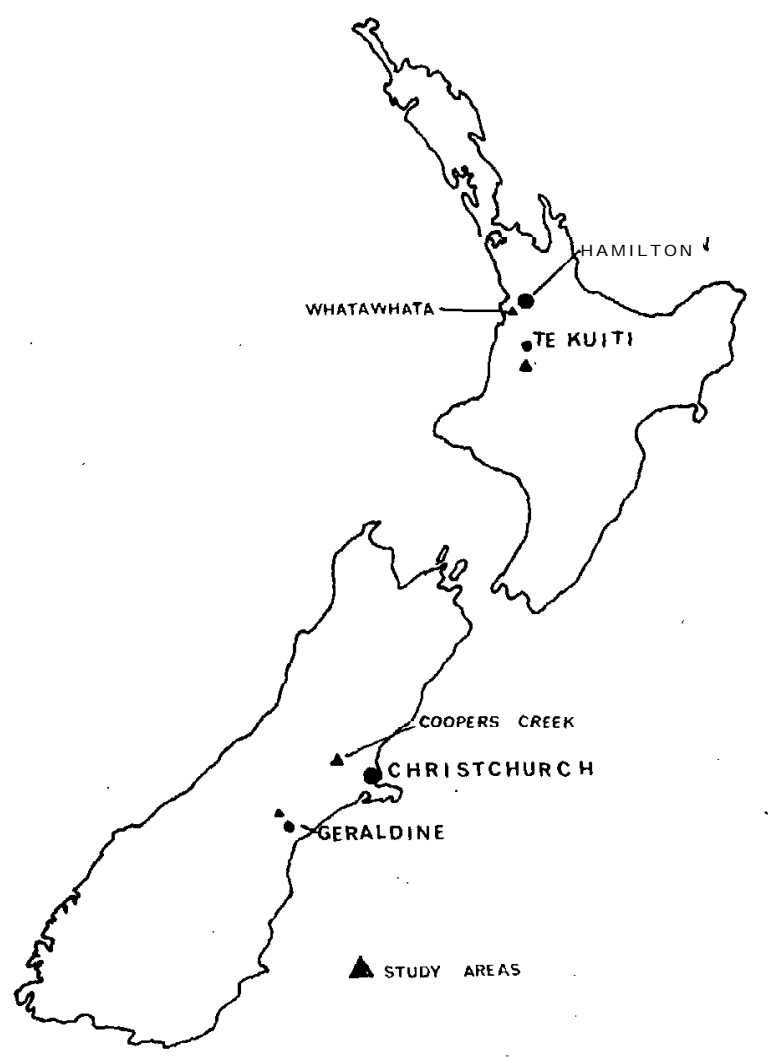

FIG. 1: Locality of study areas.

The trim technique only was used at $\mathrm{Te}$ ' Kuiti to (a) measure yields from north and south facing sites on Mahoenui steepland soil (Soil Bureau, 1954), (b) compare yields from large laxly trimmed samples and small severely trimmed samples on Mairoa ash soil (Soil Bureau, Zoc. cit.).

\section{PASTURE Composition}

Sites at Coopers Creek and Geraldine were on improved silver and fescue-tussock grasslands which were red and white clover dominant in summer. North Island sites were on improved topdressed hill country. Marked differences in pasture composition occurred both between and within study areas, but most, sites contained mainly many low to moderate fertility demanding 
grasses and weeds, some of which assumed dominance at various times of the year. Browntop, sweet vernal, Yorkshire fog, Poa species and weeds were abundant at all sites and danthonias were important at Coopers Creek and Geraldine. Perennial ryegrass occurred at Whatawhata, Te Kuiti and the ridge crest site at Coopers Creek.

\section{GRAZING MANAGEMENT}

Grazing management during the study period followed normal farm practice. At Whatawhata and Te Kuiti pastures were sometimes mob-stocked and sometimes set-stocked with ewes \pm lambs. At Coopers Creek, they were mostly set-stocked with ewes \pm lambs, and at Geraldine, they were mostly set-stocked with both ewes and cattle.

\section{Cutting Techique}

The following are details of the trim and difference techniques used in the trials.

\section{Trim}

At day 0 herbage on site $A$. was cut and discarded (the trim cut). At day $0+r z$, regrowth from $A$ was cut and weighed.

\section{Difference}

At day 0 a sampling site (A) was identified and paired with a comparable site (B) (subjectively selected within $3 \mathrm{~m}$ of A for similarity in microtopography, species composition and growth). One of the sites (say, A) was chosen at random, cut and weighed. At day $0+n$ herbage from the other site (B in this case) was cut and weighed. Production was calculated as yield from the day $0+n$ site (B) minus yield from the day 0 site (A).

Pasture was cut near ground level by electric sheep shears and soil, litter, etc., removed by hand before herbage was dried and weighed. Pasture height was not recorded, but the trim cut generally removed 500 to $1,000 \mathrm{~kg} \mathrm{DM} / \mathrm{ha}$ on well utilized sites, and up to $2,500 \mathrm{~kg} \mathrm{DM} / \mathrm{ha}$ on sites with rank pasture growth. 


\section{SAMPLING}

Some details are given in Table 1.

Cutting techniques were compared at each sampling site at Whatawhata, Coopers Creek and Geraldine. At Whatawhata these were selected at random within strata (reasonably homogeneous slopes) at each cutting date and protected from stock by small cages. At Coopers Creek and Geraldine plots were subjectively sited, then one plot was fenced, and, within this plot, sampling sites were selected at random.

On north and south sites at Te Kuiti, an arca of about $400 \mathrm{~m}^{2}$ was pegged into $1.8 \mathrm{~m}$ squares and at each cutting date samples were taken from six randomly selected. squares.

For a study of sample size and cutting height at Te Kuiti, three large cages were sited on a gentle NE sloping area, and six small cages were sited on an adjacent area. Large samples $(3.4 \mathrm{~m} \mathrm{x} 1.0 \mathrm{~m})$ were cut to $2 \mathrm{~cm}$ above ground with a reel mower every 21 days and small samples $(0.8 \mathrm{~m} \mathrm{x} 0.3 \mathrm{~m})$ were cut to $0.5 \mathrm{~cm}$ above ground with sheep shears.

\section{RESULTS}

\section{Cutting TEChIQUE}

\section{Sites}

Overall yields from the same sites differed up to $40 \%$ depending on the cutting technique used (Table 2). At Whatawhata, yields measured by the trim technique were consisten ly

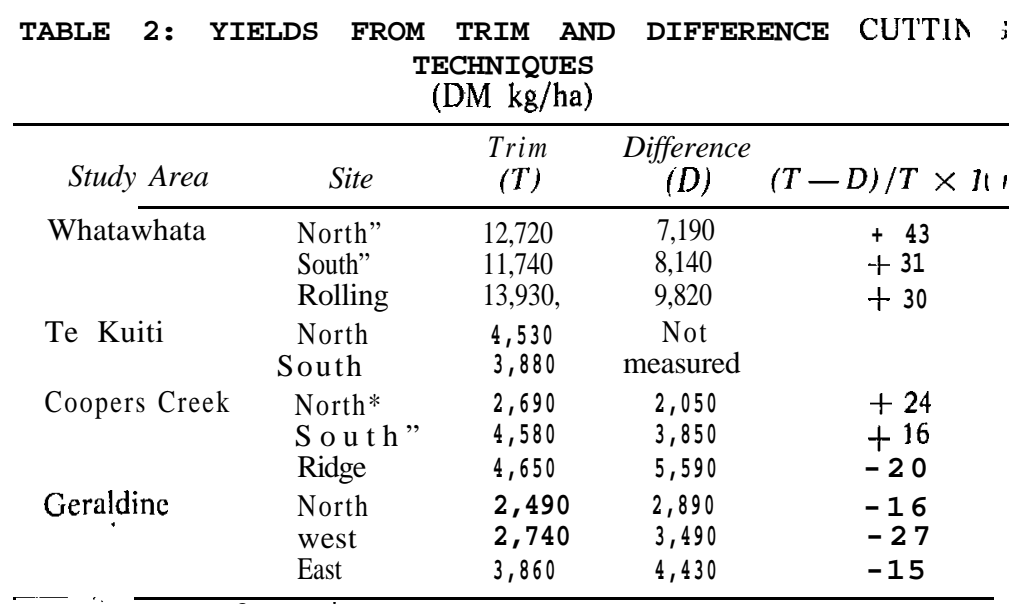

*Average yields from two sites. 
higher than yields measured by the difference technique. These differences were generally statistically significant at each cut and over all cuts $(P<0.01)$. However, at Coopers Creek and Geraldine no consistent technique effect was measured although large differences occurred at some cuts. These differences, however, were rarely statistically significant $(P>0.05)$ and they varied in direction from cut to cut. However, overall yields from 8 cuts at Geraldine suggest that here, higher yields may be measured by the difference technique.

Substantial differences in yields between techniques may also affect site comparisons - e.g., the ridge site and south-facing sites at Coopers Creek had similar yields when measured by the trim technique but the ridge site produced $45 \%$ more with the difference technique (Table 2).

At Whatawhata and Te Kuiti, the north-facing sites appeared to give higher overall yields than south-facing sites when measured by the trim technique. But at Coopers Creek and Geraldine higher yields were obtained on south and east facing sites, respectively, by the trim technique.

\section{Seasonal Growth Pattern}

This was examined only at Coopers Creek and Geraldine. In general, yields obtained by each technique showed the same seasonal growth patterns although peaks and depressions were much greater with the difference technique, particularly at those sites where large amounts of herbage, or "available dry matter" (ADM) were harvested at day 0 (Fig. 2).

As the quantity of herbage at the beginning of a measurement period could be expected to differentially influence the growth pattern obtained by each technique, this was examined at all sites, but no clear-relationship was found.

Some paired quadrats gave negative yields when measured by the difference technique but these were generally offset by positive values in adjacent paired quadrats. However, at some cuts during May to July, overall yields from some sites were negative (Fig. 2).

\section{Variability}

At all sites, the difference technique gave more -variable yields than the trim technique. At Coopers Cresk and Geraldine variability with the trim technique, as given by standard error per sample per growth period, was highly correlated with mean yields per growth period $(r=+0.8)$. A strong linear relation- 
ship $($ S.E. $=(0.36)$ yield +21$)$ indicated that yields of $500 \mathrm{~kg}$, $1,000 \mathrm{~kg}$ and $1,500 \mathrm{~kg}$ would need 16,15 and 14 samples, respectively (each $0.5 \mathrm{~m} \times 0.5 \mathrm{~m}$ ), to give a S.E. $\pm 10 \%$ of mean yield. The south sites at Coopers Creek had a smaller variance relative to the mean yield than the north and ridge sites and

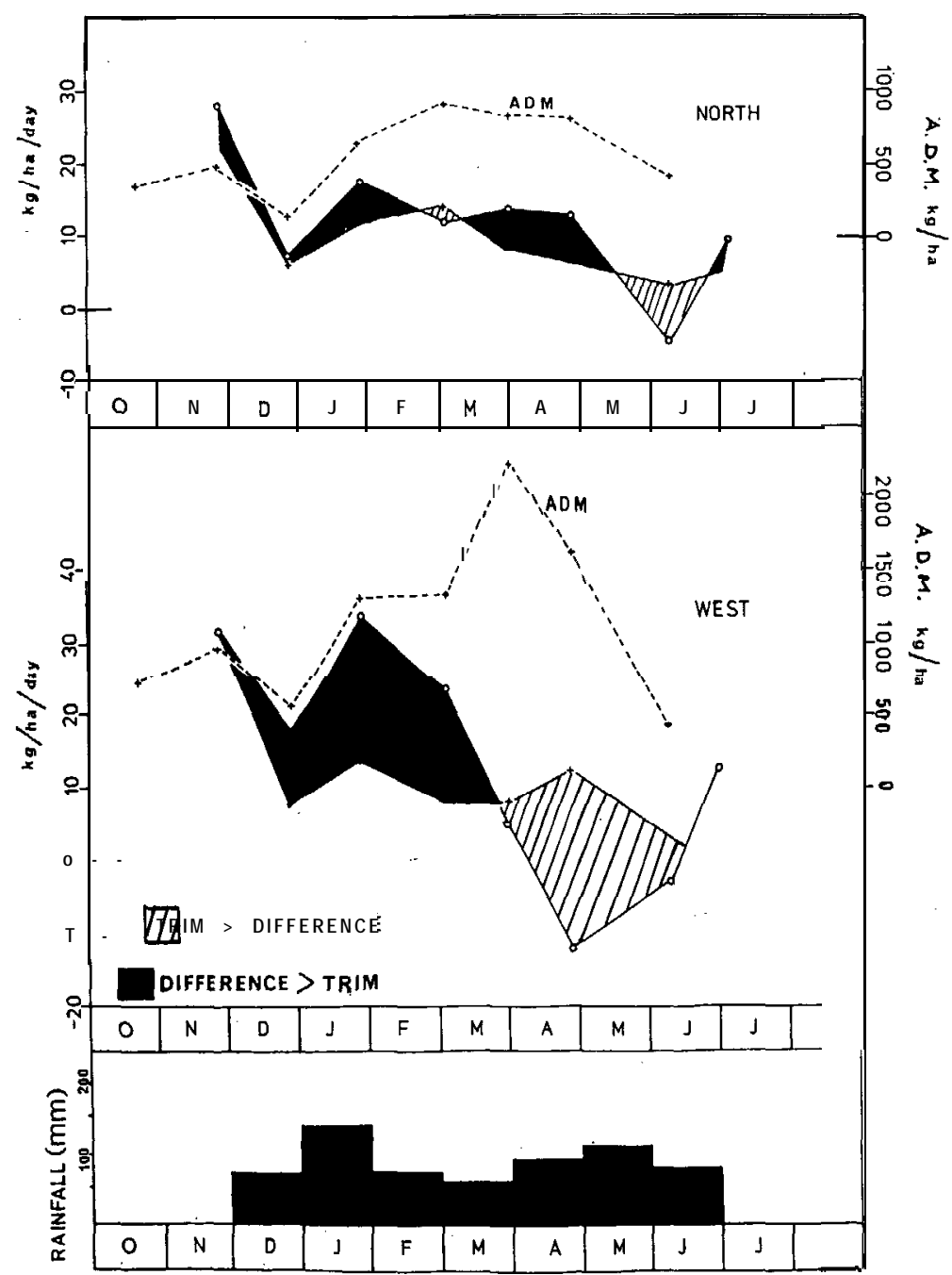

Fic. 2: Seasonal growth patterns measured by the trim and difference techniques, on north. and west-facing sites, Geraldine. 
would, therefore, need fewer samples for the same sized S.E. Standard errors obtained by the difference technique ranged from 70 to $750 \mathrm{~kg} / \mathrm{ha}$ and showed no relationship to mean yield per growth period (50 to $1,500 \mathrm{~kg} / \mathrm{ha}$ ). Here, the difference technique would require up to 20 times more samples than the trim technique in order to obtain a S.E. $\pm 10 \%$ of mean yield.

Standard errors at Whatawhata (Radcliffe et al., 1968) obtained from much smaller sampling units $(0.3 \times 0.2 \mathrm{~m})$ indicated that the trim technique would need 30 samples and the difference technique 160 samples to give a S.E. $\pm 10 \%$ of mean yield.

\section{SAMPle Size and Height of Cutting}

Yields obtained from large, laxly trimmed samples and small severely trimmed samples at Te Kuiti are illustrated in Fig. 3.

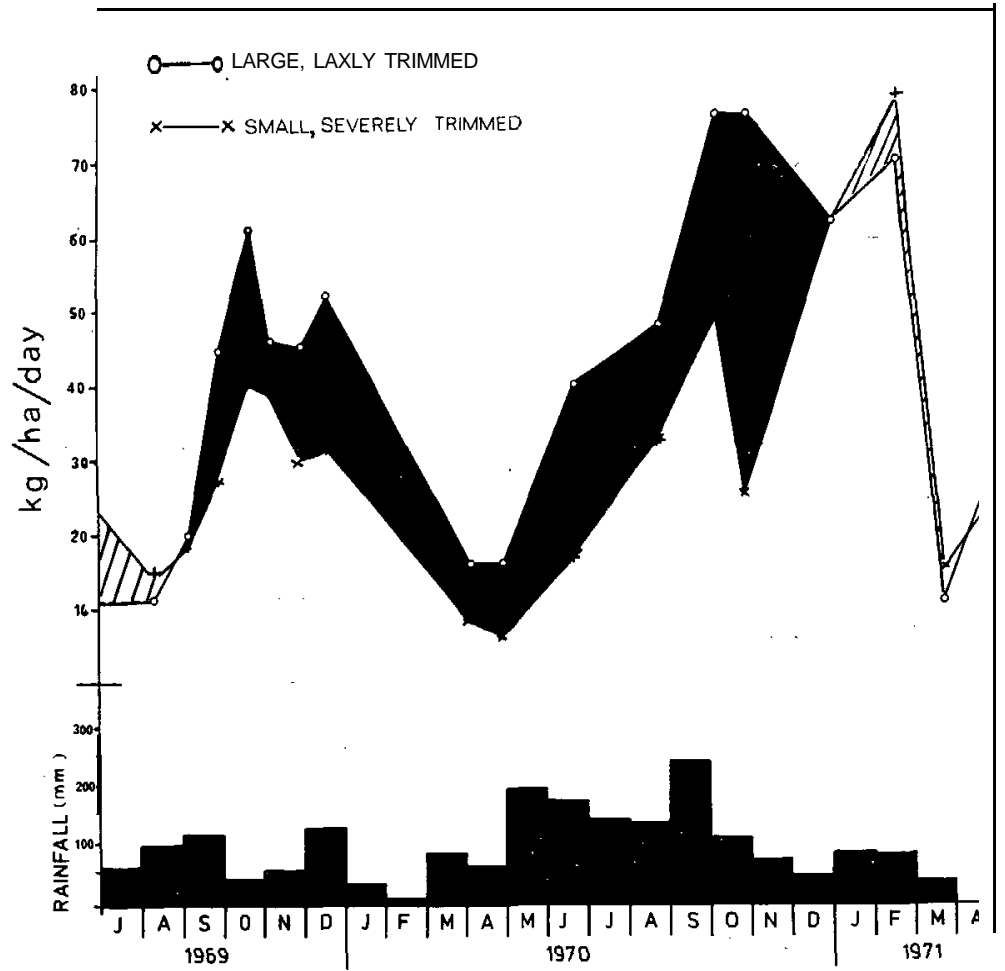

Fig. 3: Yields from large, laxly trimmed samples, and small, severely trimmed samples, Te Kuiti. 
TABLE 3: VARIANCES OF YIELDS, TE KUITI

Standard Errors (DM $\mathrm{kg} / \mathrm{ha}$ ) and the number of samples required to give a S.E. $\pm 10 \%$ of mean yield from small severely trimmed, and large laxly trimmed samples.

\begin{tabular}{ccccccc}
\hline Year & $\begin{array}{c}\text { Production } \\
\text { Level }\end{array}$ & $\begin{array}{c}\text { of Yields } \\
(D M k g / h a)\end{array}$ & S.E. & $\begin{array}{c}\text { Samples } \\
\text { No. of } \\
\text { Samples }\end{array}$ & $\begin{array}{c}\text { Large Samples } \\
\text { S.E. }\end{array}$ & $\begin{array}{c}\text { No. of } \\
\text { Samples }\end{array}$ \\
\hline $1969-70$ & & & & & & \\
& Low & $200-500$ & 155 & 16 & 80 & 3 \\
& High & $700-1,300$ & 205 & 7 & 110 & 1 \\
$1970-71$ & & & & & & \\
& Low & $500-800$ & 290 & 25 & 310 & 25 \\
& High & $1,400-2,000$ & 560 & 12 & 230 & 2 \\
\hline
\end{tabular}

*Includes a very high yield in August.

Overall yields from laxly trimmed samples were 30 to $40 \%$ higher than those from severely trimmed samples. Variances of yields during periods of relatively "low" and "high" production are shown in Table 3. Generally, one large sample gave similar precision to six or seven smaller samples, and many more samples of both sizes were needed at periods of "low" production to give a S.E. $\pm 10 \%$ of mean yield.

\section{DISCUSSION}

On most sites, cutting technique has markedly influenced yields. This effect has occurred not only between study areas, but between sites within study areas and between successive cuts on the same site. Cutting technique has also affected yield comparisons between sites.

At Whatawhata consistently higher yields were obtained by the trim technique at all sites. So far this has not been the case at Geraldine or Coopers Creek although comparable amounts of herbage have been removed at day 0. Perhaps climate, pasture components and experimental sources of variation (e.g., lower cutting height) contributed to the higher trim yields at Whatawhata. For instance, higher temperatures and well distributed rainfall may have stimulated regrowth from trimmed sites.

Growth rates of untrimmed herbage may differ substantialiy from shorter trimmed herbage but differences in growth rates will depend on plant species, habit of growih and the point at which the cutting frequency interrupts the exponential growth curve. For instance, a low pretrim cut on a prostrate plant such 
as browntop or Poa pratensis may remove some dead material yet leave enough effective leaf area to promote rapid regrowth. Conversely, other plants such as cocksfost may attain sufficient leaf area for high growth rates at a greater height above the ground. Such plants would give higher yields with the difference technique (which does not use a pretrim cut) and be soverely retarded in growth by close trimming. Clearly grazing management could affect the pattern of growth obtained by each technique and therefore it is surprising that the ADM at the beginning of a period has not differentially affected yields obtained by the trim and difference techniques. Further work may reveal clearer relationships between ADM, species, microclimate and yields.

Much more information is needed on the yield potential of resident pasture species under the various grazing managements used on hill country. This would enable yields obtained from trimmed and untrimmed herbage to be interpreted and perhaps explain why the difference technique has sometimes given much higher yields than the trim technique at Geraldine and Coopers $\mathrm{C}$ r e e $\mathrm{k}$.

However, in late autumn and early winter at Coopers Creek and Geraldine, the difference technique gave negative yields in the absence of grazing - i.e., ADM yields at day $0+n$ were smaller than those at day 0. Separation of herbage into living and dead components at each cut suggested that during this period the proportion of dead material in the ADM increased. Concurrent measurements by the trim technique gave positive yields.

The effect of cutting height and sample size on yields obtained' by the trim technique at Te Kuiti is relevant to other comparisons between yields on hill pastures, which of necessity have been obtained from small quadrats cut to ground level, arid yields on flatter pastures which have been cut with a mower to leave a longer stubble. In small samples with a large perimeter: area ratio, it is difficult to ensure that the herbage at the edges is evenly distributed inside and outside the quadrat. There is a tendency to gather in more herbage from the edges and so inflate the dry weight harvested. However, if this bias occurred, it was more than offset by the far greater yields from the $2 \mathrm{~cm}$ cutting height in larger samples. At this height, proportionately more leaf area would remain after cutting and this could convert more light energy into dry matter. 
The present use of sheep shears to cut herbage to ground level is practicable on uneven and rocky ground and minimizes operator bias. The close cutting approximates grazing height in a well utilized sheep pasture, but clearly a longer cutting height would be desirable under some management systems. Attempts to raise the cutting height of sheep shears by attaching skids have not yet proved practicable as the skids become entangled in the vegetation. Also, an "average" grazing height is extremely difficult to estimate because of the substantial variability in pasture height within small areas..

The much greater variability of the difference compared with the trim technique substantiates previous work by Nevens (1945) and Radcliffe et al. (1968) . Sources of this variability have been discussed by Green (1949). In nresent studies, in improved tussock grasslands, matching or pairing sampling sites for the difference technique has proved difficult because of very variable ground cover within small areas. These problems are aggravavated when pastures are rank and trampled by stock. Unsatisfactory pairing of sites and more variable growth from untrimmed (compared with trimmed) herbage have undoubtedly inflated the variance of the difference technique. At Whatawhata where smaller samples were cut over a larger area, the trim technique was more variable than at Coopers Creek and Geraldine where larger samples were cut over smaller areas. This may partly explain why the difference technique at Whatawhata required five or six times more samples than the trim to give similar precision, and at Coopers Creek and Geraldine it required up to 20 times more samples than the trim technique.

It is difficult to generalize from the present work on the suitability of the trim and difference techniques for hill pastures, where cutting is of necessity close to the ground and carried out at regular intervals. The trim technique is easier to operate and has an acceptable variance. It is most useful on well grazed pasture where trimming height approximates grazing height. However, at Coopers Creek, oaly clovers and flatweeds regrew in dry periods after trimming. Thus trimming can sometimes influence species composition. This disadvantage is. unlikely to occur in much North Island hill country where plentiful rainfall allows regrowth. The difference technique suffers from 2 much higher variance and the difficulty of pairing quadrats at some sites. Nevertheless, in some seasons, on laxly grazed pasture where trimming height is of necessity below grazing height, this may be the most appropriate technique to use despite its greater 
variability. The decay. of standing herbage measured by the difference technique in late autumn/early winter may be an important effect which would not be detected with the trim technique .

A valuable criterion of a cutting technique may be its sensitivity in measuring factors which affect yield such as climate and topdressing. Such assessments are under way on South Island sites. Ultimately relationships between measurements of pasture dry matter quantity and quality, and liveweight gains and other animal performance data should be examined. This is the real test of the value of any cutting technique. The very considerable practical difficulties of securing such information on hill country should not prevent this task gaining high priority in grassland research.

\section{ACKNOWLEDGEMENTS}

Many colleagues in the Department of Agriculture have made these measurements possible, in particular D. Goldsmith and Mrs B. Pownall at Whatawhata, H. Foskett at Te Kuiti, and T. Jackson and A. Gorman at Coopers Creek and Geraldine. Biometrics Section have analysed the results.

Sites are on the properties of D. Easton, K. Wells, F. Marshall and E. Lynn who are thanked for their co-operation.

\section{REFERENCES}

Boyd, D. A., 1949: I. Br. Grassld Soc., 4: 1-10.

Davies, R. 0.; Milton, W. E. J.; Lloyd, J. R., 1950: Emp. J. exp. Aq 18: 203-17.

Green, J. O., 1949: J. Br. Grassld Soc., 4: 11-17.

Lynch, P. B.; Mountier, N. S., 1954: N.Z. Il Sci. Technol., 3G A: 375-85.

Nevens, W. B., 1945: J. Dairy Sci., 28: 171-85.

Radcliffe, J. E.; Dale, W. R.; Viggers, E., 1968: N.Z. $/ l$ agric. Res., 11: $685-700$.

Soil Bureau, 1954: Soil Bur. Bull. (n.s.) 5: N.z. DSIR.

1968: Soil Bur. Bull. 27: N.Z. DSIR.

Suckling, F. E. T., 1954: N.Z. Jl Sci. Technol., 3GA: 237-73.

1964: Proc. N.Z. Grassld Ass., 26: 137-52.

\section{DISCUSSION}

Douglas (Ruakura) asked if there had been any large shift in species composition between the two techniques and whether actual tussock clumps were avoided in tussock areas. Radcliffe explained that sampling 
sites were shifted for each measurement period. Cutting once per site by the difference technique would not affect composition but one trim cut using the trim technique could possibly have an effect on subsequent growth especially in dry periods. However, any trimming effect would be confined to that particular measurement period. Tussocks were avoided as only production between them was being measured. Sites were chosen at random and, if one did fall on a tussock, another random selection would be made. Cullen (Invermay) commented that in a poorly utilized pasture the amount of herbage trimmed might well equal a hay cut at times. Radcliffe agreed that this would have a large effect and was one of the variables. Actual yields removed by trimming had varied from 500 to $1,000 \mathrm{~kg}$, with up to $2,500 \mathrm{~kg}$ for rank herbage. Joblin (Ruakura) asked for comment on the conclusions that each technique might be better for different times of the year - i.e., where utilization was good the trim technique was better but where it was poor the difference technique was better, Radcliffe agreed that each technique could be more appropriate at certain times of the year depending on growth and pasture utilization. The use of only one technique would be desirable and this may best be achieved by raising the cutting height with the trim technique, to avoid severe defoliation at those times when pasture was not being hard grazed. However, the choice of trimming height would be critical. Alternatively, more consideration could be given to sampling problems and variability with the difference technique so this could be used with more confidence throughout the year. White (Lincoln College) suggested that the differences in production between shady and sunny faces would be greater in the South than in the North Island. Radcliffe thought it would be unwise to deduce this from the data available, which were from only two sites in each island. There were large differences due to soil moisture and temperature and, perhaps, in light intensity. 